\title{
OBSERVATIONS ON PUBLIC INSTITUTIONS AND AUTHORITIES WITH THE PURPOSE OF PROTECTING INDIVIDUALS
}

\author{
C.T. POPA, F. MOROZAN
}

\section{Carmen Teodora Popa}

Faculty of Law, Department of Law

University of Oradea, Oradea, Romania

*Correspondence: Carmen Teodora Popa, University of Oradea, General Magheru St., Oradea, Romania

E-mail: bnppopacarmen@gmail.com

\section{Florina Morozan}

Faculty of Law, Department of Law

University of Oradea, Oradea, Romania

*Correspondence:

E-mail: bnppopacarmen@gmail.com

\section{ABSTRACT:}

The present work brings to the reader's attention the evolution concerning the regulation of institutions and public authorities with powers in the field of protection of the individual in Romania and, in particular, in the field of child care. Taken from the Family Code, the current tradition of civil code, through article 107, gave the Court the responsibility of guardianship and family proceedings relating to protection of the individual. Subsequently, law No. 71/2011 for the implementation of law No. 289/2009 allowed, on a temporary basis, until the entry into force of the regulation of the Board of Trustees, as courts to delegate, by closing certain tutelary authority powers. As a result of amendments to law No. 71/2011, many duties of the Board of Trustees with respect to the minor or legal forbidden were passed as the tutelary authority task.

On the other hand, the special protection of the child, law No. 272/2004 on the promotion and protection of children's rights confer important directorates-general duties of social work and child protection and child protection committees. These authorities with important powers in matters of protection of the individual have a special quality in triggering procedural active civil action such as revocation of parental rights by a court or taking of a measure of special protection. Law No. 272/2004 has set up a special material competence and liable to give rise to numerous controversies in jurisprudence.

The analysis of the development of institutions and public authorities with powers in this matter confer the opportunity to observe how the powers of the blends and the conflicts they generate in the existing not clear regulations. This article examines and interpreted that the jurisprudence has given legal provisions.

\section{KEYWORDS: Individual, organization, protection, public authorities}

\section{INTRODUCTORY CONSIDERATIONS}

For a correct application of the rules governing the protection of the individual is required the knowledge of the authorities and institutions that have competence in certain subjects. In the legislation, the public authority is defined as any State organ or 
administrative-territorial unit acting under State authority, to satisfy a legitimate interest (article 2, point 1, letter b of law No. 554/2004 of the administrative courts) ${ }^{1}{ }^{1}$

It is necessary to distinguish the old legislation, especially the family code, and the new legislation starting with law No. 272/2004 on the protection and promotion of children's rights and culminating in the civil code and by the law for its implementation. The presentation of the legal provisions from historical perspective will demonstrate that the current regulation is the fruit of a gradual development of legislation for the purposes of assigned powers in favor of the Court. At the same time, we noticed the hesitation and explicable through a legislative assessment of material resources and unrealistic that resulted in recognition, again, has numerous powers in favor of the tutelary authority.

\section{REGULATION PREVIOUS THE LAW. 272/2004 ON THE PROTECTION AND PROMOTION OF THE RIGHTS OF THE CHILD}

Under the Family Code, powers relating to measures for the protection of an individual was divided between the guardianship authority and the court stating that the role of the most important has been the tutelary authority. Under art. 158 Fam. Code, the tutelary authority powers belong to the executive bodies and provision of local councils or districts of Bucharest. The powers of the supervisory authority were tutelary, of control and referral to the Court ${ }^{2}$.

Of the most significant tasks of the tutelary authority governed by the family code: resolving disagreements between parents regarding the exercise of rights or the fulfillment of parental duties (art. 99 fam. c.), control the way in which parents fulfill their duties regarding the person and property of the child (art. 108 fam. c.), changing the way the enforceability of vocational training institutes to the minor times at the latter's request (art. 102 fam. c.), enforceability of adoption (art. 73 fam. c.), the establishment of guardianship and supervision of the exercise of guardianship (art. 126-141, art. 116 fam. c.), the establishment of special or trusteeship of proper Trusteeship (art. 132, 139, 146, 152 and following Code), the appeal court for the forfeiture of parental rights of the parent (art. 109 fam. c.) or for a person under prohibition (article 143 fam. c.).We observe that the legislature will transfer in time, the most important tasks of the tutelary authority towards the courts of law.

Regarding the taking of the measure in relation to minors in such situations, according to law No. 3 of 26 March 1970 relating to the protection of some categories of minor powers belonged to the Executive Committee of the popular County Councils (CPJ) or of Bucharest by the organ of social work and child protection Commission ${ }^{3}$. Under art. 12 of law No. $3 / 1970$, child protection committees were an addition to the executive committees of councils and County folk of Bucharest. Against the decisions of the Commission for the protection of minors, parents or guardian, the family or the person to whom the minor has been entrusted, the Prosecutor and the guardianship authority, as well as the minor could appeal within five

\footnotetext{
${ }^{1}$ Relatively recently, the High Court of Cassation and justice, in decision No. 28 of April 24, 2017 prior to issuing a decision to tighten the law issues relating to the notion of "public authority"; According to the High Court, the notion of "public authority", as defined by art. 2 para.1 let. (b) and law no. 554/2004, with subsequent amendments and additions, there is similar to that of "public institution", as provided by art. 2 para. 1, point 39 of the law no. 273/2006 concerning local finances, with subsequent amendments and additions. Decision No. 28/2017 was published in O.M. No. 378 dated May 22, 2017.

${ }^{2}$ I. Albu, The family law, Teaching and Pedagogic Publishing House, Bucharest, 1975, p. 323.

${ }^{33}$ Law No. 3 of 26 March 1970 relating to the protection of some categories of minors had in art. 2 para. 2 : "Family Placement is made with the parents' or guardian agreement by the CPJ's Executive Committee or of Bucharest through welfare body '. According to article 3 para 1 of the same regulatory action, "If the juveniles seen in art. and it was not possible to take the measure of the family, as well as placement in the event that the development of physical, moral or intellectual minor is jeopardized, the Commission for the protection of minors can decide to entrust him to a family with his consent."
} 
days of the notification to the Court in whose area the minor resides (art. 17 of the law No. 3/1970).

The Emergency Ordinance No. 26 of June 9, 1997 on the protection of children in difficulty grants powers to the commissions for the protection of the child. In order to establish measures for the protection of children in difficult situations, subordinated to the County Council, the local councils of the sectors of Bucharest, organized and provided the Commission for child protection and the specialized public service for child protection (art. 4 para. 2 of ORDINANCE No. 26/1997).

Under art. 5 of OUG No. 26/1997, the Commission for child protection was the specialty of the local Council or of the municipality of Bucharest' sectors fulfilling the duties provided for in the Emergency Ordinance, relating to the establishment of measures for the protection of children in difficulty and to relations with the specialized public service for child protection. The Commission for child protection have legal powers among and coordination of activity of local public administration authorities in the administrative territory of the County, in the field of tutelary authority and the protection of the rights of the child.

With regard to the protection of the elderly, art. 30 of law No. 17 of 6 of March $2000^{4}$ concerning the social welfare of older persons gave away the jurisdiction of the guardianship authorities, representatives of the local authority Council where the elder person lives and assisting the elderly person residing upon request or ex officio, as appropriate, having in mind the conclusion of a legal act of alienation, whether for a consideration or free of charge, in assets that belong to them, for the purpose of his maintenance and care.

Later, art. 30 of law No. 17/2004 was amended by law No. 270/2008 who issued the obligation of protection authority or, where appropriate, of legal advisers employed by the local Council in whose territorial radius are residing elderly people "to provide, at request, free advice in concluding legal acts of sale, donation or real estate guarantees loans that have as their object movables or immovable property of the concerned elderly person". Also, to the elderly person it is recognized the right to be assisted by a representative of the guardianship of the City Council in whose territorial radius he resides at the conclusion of a legal act of alienation, with consideration of the time free of charge in assets that belong to him, for the purpose of his maintenance and care.

Later, art. 30 of law No. 17/2004 was amended by law No. 270/2008 who issued the obligation of protection authority or, where appropriate, of legal advisers employed by the local Council in whose territorial radius are residing elderly people "to provide, at request, free advice in concluding legal acts of sale, donation or real estate guarantees loans that have as their object movables or immovable property of the concerned elderly person". Also, to the elderly person it is recognized the right to be assisted by a representative of the guardianship of the City Council in whose territorial radius he resides at the conclusion of a legal act of alienation, with consideration of the time free of charge in assets that belong to him, for the purpose of his maintenance and care.

In the previous law. 272/2004, some limited powers were under the jurisdiction of the courts of law. Thus, the court decided the forfeiture of parental responsibility (article 109 fam. C), resolve the disagreement between the parents regarding the child's home (art. 100 fam. C) and those of the minor and the parents (art. 107 fam. C), entrust the child into the education and growth of one of the parents (art. 42 para. 1 fam. C), amend the measures concerning personal rights and obligations between divorced parents or heritage and children (art. 44 fam. C) the substance of the request, the parents concerning the return of the child from any person holding him without a right (art. 103 fam. C) or an application for judicial

${ }^{4}$ Law No. 17 of March $6^{\text {th }} 2000$ concerning the social welfare of older persons was published in the Of. M. No. 104 dated $9^{\text {th }}$ of March 2000. The law was subsequently republished in Of. M. No. 157 dated March $6^{\text {th }} 2007$. 
release under prohibition (art. 144 c. fam.). Subsequently, based on article 1 of law No. 11 of $31^{\text {st }}$ of July 1990 , the courts had the competence of adoption.

We must mention the amendments which the legislation has suffered concerning the protection of persons with mental disorders. The Decree No. 313 of October $14^{\text {th }} 1980$ concerning assistance to sick mentally hazardous people, allowed taking the measure of compulsory medical treatment by decision of the Commission (art. 9 of the Decree). The legality of the internment was checked, periodically by the Prosecutor's Office (article 23 of Decree) and the measure could be challenged in court (art. 24 of the Decree).

The Decree No. 313/1980 was repealed by law No. 487 of July11 2002 for mental health and the protection of persons with mental disorders ${ }^{5 .}$ In the original form of the law, the decision of an individual involuntary internment in a psychiatric service was confirmed by a review of the procedure being subjected to the Auditing Commission and the competent court can be appealed to a court (art. 52-54 of law No. 487/2002). In this first version of the law, the Court was competent to hear the appeal only the patient (or legal representative or the staff thereof) against the involuntary internment. In its current form, republished, internment decision of the Commission shall be subject to confirmation of the Court in whose district the medical unit is located (article 61 para. 6 of law No. 487/2002 republished).

\section{LAW NO. 272/2004 ON THE PROTECTION AND PROMOTION OF THE RIGHTS OF THE CHILD 6}

An important step in regulating the authorities in matters of child protection has been made in the year 2004, by law No. 242/2004 on the protection and promotion of children's rights, with value of principle, public authorities with powers in the field of childcare: subordinated to the County Council and the local councils/ of the sectors Bucharest, the Commission for child protection worked as a specialized body, without legal personality, with the following main tasks: determining their classification and school orientation and disability of the child according to the law no. 272/2004, regarding the proposals concerning the establishment of a special protection measures, the settlement on the issue of the certificate of a care assistant and other powers provided by law (article 104 of the law No. 272/2004). Subsequently, the organization and functioning of the Commission's methodology for protection of children is regulated by the Government Decision no. 1437 from September $2^{\text {nd }} 2004^{7}$. The duties of the Commission for child protection have been enlarged by Decision No. 502/2017 regarding the organization and functioning of the Commission for child protection.

Another step was the establishment, in accordance with article 105 para. 1 of the law No. 272/2004, the General Directorate of social assistance and child protection, by reorganizing the specialized public service for child protection, the county councils and subordinate to the local councils of the sectors of the municipality Bucharest, as well as the public welfare of the counties and Bucharest sectors. According to. Art. 105 para. 2 of the law No. 272/2004 the General Directorate of social assistance and child protection is a public institution with legal personality, subordinated to the County Council, the local councils of the sectors of Bucharest, who took over, accordingly, the public service functions of social

\footnotetext{
${ }^{5}$ Law No. 487 of 11 July 2002 mental health and the protection of persons with mental disorders was published in the Of. M. number 589 dated august $8^{\text {th }}$ 2002. The law was subsequently republished in Of. M. no. 652 dated $13^{\text {th }}$ of September 2012.

${ }^{6}$ Law No. 272/2004 on the protection and promotion of the rights of the child was published in Of. M with the number 557 dated $23^{\text {rd }}$ of June 2004. The law was subsequently republished in Of. M number 159 dated March $5^{\text {th }}$, 2014. Law No. 272/2004 was amended by law No. 52 of $30^{\text {th }}$ of March 2016 for the modification and completion of the law no. 272/2004 on the protection and promotion of children's rights published in Of. M No. 253 dated $5^{\text {th }}$ of April 2016.

${ }^{7}$ Government decision No. 1437 of 2 September 2004 on the organization and functioning of the Commission's methodology for the protection of children was repealed by Decision No. 502/2017 on organization and functioning of the Commission for the protection of children published in Of. M No. 596 of $25^{\text {th }}$ of July 2017.
} 


\section{OBSERVATIONS ON PUBLIC INSTITUTIONS AND AUTHORITIES WITH THE PURPOSE OF PROTECTING INDIVIDUALS}

assistance from the County and the public service duties of social assistance in the sectors of Bucharest.

According to the framework regulation of $2^{\text {nd }}$ of September 2004 on the organization and operation of the General Directorate of social assistance and child protection, the General Directorate of social assistance and child protection is to ensure the county level respectively at the level of sectors of Bucharest, the implementation of policies and strategies for social work in child protection, family, single persons, senior citizens, people with disabilities, and any person in need (art. 1 para. 1 of the framework regulation).

At central level, monitoring the compliance with children's rights and control of protection and promotion of children's rights was done by the national authority for protection of children's rights, the specialized body of the central public administration, with legal personality, subordinated to the Ministry of labor, social solidarity and family (article 100 of the law No. 272/2004 in its initial form). Subsequently, through art. I, section 70 of the Act no. 257/2013 for the modification and completion of the law no. 272/2004 on the protection and promotion of the rights of the child ${ }^{8}$, which was published in the Official Gazette of Romania, part I, no. 607 of September $30^{\text {th }}$, 2013, the phrase "national authority for protection of children's rights" was replaced with the words "Ministry of labor, family and social protection of older people".

Locally, the Law 272/2004 established powers in favor of the public services of social work organized at the level of municipalities and cities, as well as people involved in the welfare of the local councils and municipal (art. 106). In addition, law No. 272/2004 was setting in art. 102 the obligation of the local Government to guarantee and promote respect for the rights of children in administrative-territorial units, ensuring the prevention of separation of his parents, as well as special protection the child temporarily or permanently deprived of his parents' care.

The Law No. 272/2004 has marked the moment of transmission of some powers in matters of protection of the individual from the tutelary authorities by courts of law. Thus, art. 40 of law no.272/2004 was establishing the guardianship was that "in accordance with the law by the Court in whose territorial jurisdiction the baby was residing and found".

Concerning the establishment of special measures for the protection of minors, the Law no. 272/2004divided powers between the commission for child protection (establishment of the placement measure in accordance with article 61 of the law No. $272 / 2004$ or taking the measure of supervision specializing in accordance with art. 67 para. 2 of the Act), the Director of the General Directorate of social assistance and child protection (placement in emergency regime in accordance with article 65 of the law no. 272/2004) and the Court. The General Directorate of social assistance and child protection has the task of preparation of individualized plan.

The Court, in some circles, had the competence to take a measure of special protection where there is opposition on the part of persons in whose care was the minor (art. 61, para. 2, art. 65 para. 2 and art. 67 para. 2 of the law No. 272/2004). In addition, the Court was competent to rule in connection with the maintenance of the measure as a matter of urgency of the program when it was taken by the Director of the General Directorate of social assistance and child protection (article 66 from Law No. 272/2004).

The Law No. 272/2004 contained in art. 124 (the current art. 133 after republishing) rules derogating from the common law in relation to the jurisdiction of the courts of law. It disposed: "the causes provided for in this Act concerning special protection measures within the competence of the Court of the domicile of the child. If the child's domicile is not known, the competence lies with the Court in whose territorial jurisdiction, the child was found."

${ }^{8}$ Law No. $257 / 2013$ for the modification and completion of the law no. 272/2004 on the protection and promotion of the rights of the child was published in Of. M of Romania, part I, no. 607 of 30 September 2013. 
This special jurisdiction laid down in article 124 of the law no. 272/2004 has drawn controversy in the cases that have been resolved through the delivery of the High Court of Cassation and justice of some appeals in the interest of the law. Thus, by decision No. III from 15 th of January 2007 the High Court of Cassation and Justice -United Sections, established the material jurisdiction at first instance settlement of the claims to the extent of protection alternative of child guardianship in favor of the court, as a Court of common law, and not the court at the child's home, by virtue of special competence established by law No. $272 / 2004$.

In a separate decision ${ }^{9}$, also in connection with the special jurisdiction established by art. 133 para. 1 of the law No. 272/2004, the High Court of Cassation and Justice declared in the interpretation and uniform implementation of the provisions of art. 85 paragraph 2 of law No. 448/2006 on the protection and promotion of the rights of persons with disabilities. The Supreme Court has established jurisdiction to settle in the first instance disputes involving the annulment of decisions of the Commission for child protection of employment grade and type of disability of the child with disabilities in favor of the courts- administrative departments specializing in the matter of the administrative courts and the special jurisdiction provided for by art. 133 of the law no. 272/2004.

According to the High Court, the aspect of that law. 272/2004 includes specific rules with regard to children with disabilities do not justify the conclusion that litigation aimed at challenging the decisions of the Commission for protection of a child's degree of disability shall be subject to the jurisdiction provided in article 133 of the law no. 272/2004, derogating from the common law, in the field of protection and promotion of the rights of persons with disabilities there is a special law which does not differentiate in regard to its scope between children and adults with disabilities.

The fact that only in respect of decisions of the Evaluation Committee, law No. $448 / 2006$ provides that they may be appealed to the superior assessment of adults with disabilities in the structure of the Ministry of labor, family and social protection, under art. 87 para. (5) of law No. 448/2006, and decisions issued by the Commission may be appealed to the superior Department of administrative and fiscal court according to law. 554/2004 [the 902 para. (4) of law No. 448/2006], that means that in terms of decisions contested and issued by the Commission for the protection of children, employment in a degree of disability, the competence of solving would belong to other than the instances of administrative law.

The competence of administrative courts has been established by the High Court of Cassation and Justice and in the case of unsuccessful actions whereby a claim by the Directorate General of social welfare and child protection order of a Council County or local or other general directions of social work and child protection at the costs of maintenance for persons who benefit from the protective measures provided for by law No. 448/2006. In this respect, by decision No. 13 of $22^{\text {nd }}$ of June $2015^{10}$ the High Court of Cassation and Justice has decided regarding the interpretation and application of the provisions of art. 2 para. 1 let. $\mathrm{f}$ and article. 10 of the law on administrative courts no. 554/2004, as amended and supplemented, and the art. 94 and 95 of the code of civil procedure regarding the nature and competence of solving these cases.

The Supreme Court ruled that these actions are within the competence of administrative courts. It was noted that the disputes concerned fall within administrative judgments given the quality of the public authorities of the parties, that the object of these actions is the refusal of applications relating to a right provided by law and the legal nature of the rights and obligations of the corrective to finance the social security system, as one of

${ }^{9}$ Decision No. 1 of $30^{\text {th }}$ of January 2017 delivered in an appeal in the interest of the law was published in Of. M. of Romania, part I, no. 223 dated $31^{\text {st }}$ of March 2017.

\footnotetext{
${ }^{10}$ Decision No. 13 of the High Court of Cassation and Justice delivered in an appeal in the interest of the law was published in the Of. M of Romania, part I, no. 690 of $11^{\text {th }}$ of September 2015.
} 
administrative law; the fact that the object of the dispute is the claim of civilian was not considered definitive, as long as they are not fount in civil legal relationships, but in the law.

\section{LAW NO. 287/2009 REGARDING THE CIVIL CODE AND LAW NO.71/2011FOR ITS APPLICATION}

The above legislation, that the powers of the Court, reflect the will of the legislator to ensure access to justice as the prerogative of the right to a fair trial. ${ }^{11}$ Art. 104 of the law no. 287 of $17^{\text {th }}$ of July 2009 concerning the civil code was: "procedures set out in this code regarding the protection of the person through the guardianship and Trusteeship are the competence of the Court of guardianship and family established according to the law, the Court of guardianship". The text of the law, not just grants the important powers of the courts but also dedicates a new category of specialized courts courts-family and guardianship.

Although the intention of the legislator as expressed through art. 104 of the law no. $287 / 2009$ regarding the civil code was welcomed in order to submit to the judicial control measures of maximum importance for the individual, its implementation has proved not to be possible.

Thus, neither at the date of the adoption of the law No. 287/2009, nor later, at the time of entry into force of the new civil code -October $1^{\text {st }}, 2011$, have not yet been established by the courts of guardianship. An attempt was made to remedy this shortcoming through law No. 71 in June $3^{\text {rd }} 2011$ for implementation of the law. 287/2009 relating to the civil code. Under art. 229 paragraph 1 thereof, organization, functioning and powers of the Court of guardianship and family were to lay down the law on judicial organization. The text of articles 229 included important provisions applicable before regulation by law of the Organization and functioning of the Court of guardianship. Thus, its powers, provided for in the civil code, were to be met by the courts, departments or, where appropriate, specialized juvenile and family commission. Similar provisions we also see in the article 76of Law No. $76 / 2012$ for the implementation of law No. 134/2010 relating to the code of civil procedure: "to organize family and guardianship courts or, where appropriate, the specialized courts for minors and family will fulfill the role of the Court of guardianship and family, having the competence as established by the civil code, the code of civil procedure, the present law, as well as special regulations in force ".

Pursuant to law No. 71/2011, the authorities and institutions involved in the protection of the rights of the child, the individual, continues to exercise the powers provided for by the regulations in force at the date of entry into force of the civil code, except those given in the Court of guardianship. Also, pending the entry into force of the regulation on the Organization, functioning and powers of the Court of guardianship and family guardianship, the Court may delegate, by closure, some of these guardianship (Law. $71 / 2011$, its initial form). The text of article 229 para. 3 of the law No. 71/2011 take account of the performance of duties relating to the exercise of guardianship with respect to the assets of the minor or, where appropriate, with regard to the supervision of the way in which the tutor administers the minor's belongings.

The text of article 229 of law no. 71/2011 has undergone several changes that reflect a "setback" for the purposes of that legislation powers which for a long time have been the tutelary authority jurisdiction were under played, gradually modifying texts, in their jurisdiction.

Thus through art. 1 point 22 of law No. 60 of $10^{\text {th }}$ of April 2012 approving Government Emergency Ordinance no. 79/2011 for necessary measures to regulate the entry into force of law No. 287/2009 concerning the civil code is that those powers which had the

\footnotetext{
${ }^{11}$ The right to a court is the first guarantee conferred any justice maker for the existence of a fair trial-G. Boroi, M. Stancu, The Civil procedure law, Hamangiu, 2015, p. 11.
} 
initial form of the law 71/2011 could just be "delegated" tutelary authority, "incumbent" tutelary authority pending the entry into force of the provisions concerning the Organization and functioning of the Board of Trustees. Guardianship authority ${ }^{12}$ takes over the powers of the Court of guardianship law relating to the exercise of guardianship with respect to the assets of the minor or, where appropriate, with regard to the supervision of the way in which the tutor administers the goods.

Later, by article 1, section 2 of law No. 214 of $28^{\text {th }}$ of June 2013 for approving Government Emergency Ordinance no. 4/2013 amending the law No. 76/2012 for the implementation of law No. 134/2010 relating to the code of civil procedure, as well as for the modification and completion of some legal acts related to entrusted guardianship authority take over and the Board of Trustees concerning the exercise of guardianship with respect to the goods forbidden to court, or, as appropriate, with regard to the supervision of the way in which the tutor administers its goods.

The case-law of the courts was not one in terms of the application of the legal provisions relating to the discharge of the guardians. Some courts, after a prior checking by the guardianship authority annual reports presented by tutors, have disposed through court decision, discharge of guardians. Taking into account the transfer under the law to legal duties regarding supervision of the guardian from the courts to the tutelary authorities, we consider as an unlawful sentence the one recorded in the entry in force later, the Law No. 214 of $28^{\text {th }}$ of June 2013, the Court and its jurisdiction, agreed for the report of the year 2013, presented by the applicant regarding the way the guardian-who managed the assets and income of the person placed under ban in Bistriţa and requested discharge for the year 2013 to the claimant, as a guardian of that person. ${ }^{13}$

Other court seized by the guardians to receive discharge of management, have ordered reports to be sent to the Guardianship Court in order to grant discharge, because is the competent institution, in accordance with the provisions of article 229 paragraph 3 of law No. $71 / 2011$, to give such a discharge.

There is controversy in the courts and in practice as regards the approval of the closure of certain acts. From this point of view, in a sentence, legally, it was dismissed as inadmissible the application the legal representatives of a minor under the age of 14 years on the approval by the Court of the concluding acts of provision in favor of minors at court that "there are currently no laws under which court to authorize the conclusion of documents available." The solution has been upheld by the Court in Constanța, considering that "from the date of referral to the Court with this application, the Court no longer has jurisdiction to hear and determine any such application, the applicant should address to the authority protection that will proceed to the appointment of special trustee and shall assist or represent the minor at the conclusion of the provision at the request of the public notary, in the latter case there's no need of validation or confirmation by the Court ". ${ }^{14}$

Although the decision rejecting the application for appeal is correct, her recitals are not sheltered from criticism by depicting a regrettable confusion which is sometimes made by the courts of law. Thus, the Court of appeal did not distinguish between the requested authorization for the conclusion of a provision and the demand for appointment of a curator. Trustee appointment specifically for minor aims the minor located in any of the situations

\footnotetext{
${ }^{12}$ For an in-depth analysis of the duties of the Board of Trustees see B. D. Moloman, Considerations relating to the jurisdiction of the guardianship authorities under the auspices of the new legal regulations, Pandectele Române" no. 7/ 31 July, 2014.

${ }^{13}$ Court of Bistrita, Civil Department, the Chamber hearing of the Council of $21^{\text {st }}$ of May 2014, conclusion no. 4168/2014, http://www.rolii.ro.

${ }^{14}$ Court of Constanta, civil department, decision No. 745 of 16 October 2014, http://www.rolii.ro.
} 


\section{OBSERVATIONS ON PUBLIC INSTITUTIONS AND AUTHORITIES WITH THE PURPOSE OF PROTECTING INDIVIDUALS}

referred to in art. 150,159 or $167 \mathrm{Civ}$. Code ${ }^{15}$.On the other hand, approval is a formality what must be accomplished prior to the conclusion of a legal act by the representative which cannot conclude due to the lack of such formalities, acts of provision (article. $144 \mathrm{Civ}$. Code). In this case those under age were represented, though it was not necessary, to the appointment of a special curator, authorization being required only by the Trustees. Be prejudicial to this distinction may lead to a solution, not just wrong but funny, in which the father to be named curator of his own child!

Pending the entry into force of the regulation of the Court of guardianship, the law implementation has remained civil code and the rules of law 272/2004 regarding the establishment and monitoring of placement the placement measure, emergency and specialized supervision (article 229 of Act No. 71/2011 Law No. 60/2012). As I mentioned earlier, taking such measures is, according to law No. 272/2004 where appropriate, the responsibility of the Commission for child protection, the Directorate (the Director) of social work and child protection or the proceedings of the Court.

The Law No. 60/10 ${ }^{\text {th }}$ of April 2012 to tutelary authority and competence for appointing special trustee shall assist or represent the minor at the conclusion of the debate available or inheritance following the procedure, this is to be done as soon as the authority guardianship, at the request of the public notary without needing validation or confirmation by the Court (article. Law No. 66/2012, article 1, point 22). Through art. III point 1 of law No. 54 of $14^{\text {th }}$ of March 2013 approving Government Emergency Ordinance no. 120/2011 concerning the extension of certain time limits and on modification and completion of some legislative acts on these legal provisions are applied properly and if the trustee appointment specifically referred to in art. 167 of the civil code and in the case of need and to the resolution of the request for judicial release under interdiction, to care for and representation of the one whose ban was required, as well as for the management of its assets.

Other measures of protection still remained within the competence of the Court such prohibition or curatorship. In accordance with article 114 Procedural civ. code, if the law does not stipulate otherwise, applications relating to the protection of the individual data of the civil code the Court of guardianship and family court in deciding whose territorial constituency is domiciled or the residence of the protected person. In the case of applications relating to the authorization of the Court of guardianship and family of conclusion of legal acts, when legal document whose approval is sought relates to a building, is also competent the court in whose territorial jurisdiction the property is situated. In this case, the Court of guardianship and family who pronounced the judgment will immediately communicate a copy of it to the Court of guardianship and family in whose territorial constituency is domiciled or resides the guarded one.

Rules establishing jurisdiction in making arrangements for the protection of an individual are the exclusive territorial competence rules. For instance, art. 179 Civ. code which establishes jurisdiction in claims relating to the protection of the individual through the Trusteeship Institute a territorial jurisdiction, depending on the legal assumptions for establishing Trusteeship, provided for in art. 178 Civ. code in favor of the Court of domicile of the person represented, or that of the place where the emergency measures should be taken or the last place of residence in the country of the missing or the disappeared. In the case under a judicial prohibition, jurisdiction lies with the court settlement of Trustees in whose constituency resides.

\footnotetext{
15 In the sense that the trustee may be instituted in the case where there are contrarieties of interest between representative and minor but only "simple reasons likely to hinder him to attend/represent the minor" see L.C. Ureche and B.M. Moloman, The analysis the provisions of paragraphs 2 of art. 150 NCC. The issue of setting up Trusteeship in the situation of the lack of interest among contrary to the minor and his legal representative, Romanian Journal of Law No. 2 of 30 April 2014.
} 
Having a solution to the conflict between the two powers of justice in a case concerning a person under restraint, the Court of Bucharest established jurisdiction settlement in favor of Sector 3 Court of the domicile of the intimate, not the specialized center where the person was for a specified period. It was considered that it wasn't relevant "that, for a specified period, the person placed in a specialized Centre within the sector cannot be considered a residence nor domicile in fact where the defendant would inhabit actually, to the competence of sector 1 Court". ${ }^{16}$ In the settlement of another conflict of jurisdiction in connection with the establishment of the Trusteeship to the Court of Bucharest, the person has noted that "interest in the jurisdiction at the time of introduction of the domicile of the parties, the Court legal action hearing the competent, even though remaining subsequent intervening changes in this respect." ${ }^{17}$ Accordingly, the Court in Bucharest determined that, in question, jurisdiction shall lie with the Court in whose area of jurisdiction the main person has his home at the time of the promotion action.

In judicial practice, there were controversies and as regards the complaint against the tutelary authority's refusal to authorize the conclusion of any specific act. In a case of the Court of Timiș ${ }^{18}$ the administrative and tax section, has been found negative conflict of jurisdiction between the Courts of Justice in Timișoara, action in which the plaintiff sought an order directing the defendant in Timişoara, Guardianship Authority to give consent in relation to investing some monies of the appellant in the name and on behalf of his minor children in shares in various companies, for the purpose of collection dividends. Guardianship authority previously refused authorization by the Act conclusion, the father saying that the transactions for which the authorization is requested would not pose undoubted benefit for minors whereas it involved a hazardous situation incompatible with the interest of their heritage.

The regional court in Timisoara where was the application that had to formulate an appeal against an act issued by the local public authority, pursuant to art. 10 paragraph 1 of the law No. 554/2004 and therefore within the jurisdiction of the settlement of the case in favor of the Court of Timiș. This, in turn, invoked the exception to disposing of believing that there is a dispute concerning administrative acts issued or entered into by local public authorities and County that handled the background by the administrative courts. The circumstance that the Court in Timisoara has delegated authority guardianship responsibilities of these legal acts, authorizations, does not change anything nor to attract the Court jurisdiction.

\section{CONCLUSIONS}

The purpose of this brief incursion into the history of regulations in the field of physical protection was not the exhaustion of the issue addressed, but only the illustration of the evolution of the institutions in time and the identification of the sources of numerous controversies. The limited space did not allow us to discuss other related topics such as disputes concerning the authorization required for the conclusion of certain acts by the incapacitated or restricted person. Often, those interested in obtaining an authorization are caught between the misunderstandings between the guardianship authority and the courts, without being able to complete their approach.

As we have shown before, legislative hesitations have led us to a point where sometimes the courts are not guided. This is detrimental both to the individual who often does not know whom to address, as well as to justice.

\footnotetext{
16 The Bucharest Court, Civil department, civil sentence no. 27 of the meeting room of the Council from 13.01.2014, http://www.rolii.ro.

${ }_{17}$ The Bucharest Court, Civil department, civil sentence nr no. 1079 from 6.10.2014, http://www.rolii.ro.

18 Court in Timiș, Section of administrative law and tax, sentence no. 1320/12th of October 2015, http://www.rolii.ro.
} 


\section{OBSERVATIONS ON PUBLIC INSTITUTIONS AND AUTHORITIES WITH THE PURPOSE OF PROTECTING INDIVIDUALS}

We believe it would be beneficial for the attributions in the matter of the protection of the individual to be definitively brought to the competence of the guardianship authorities by giving up the role of the courts with these attributions. And from the point of view of taking a measure with speed, we believe it is desirable that the attributions in the matter of the protection of the person remain, as in the regulation of the Family Code, to the responsibility of the guardianship authorities. Courts should only be given the power to verify the legality and, possibly, the soundness of the measure taken by public authorities to ensure free access to justice.

The purpose of this brief incursion into the history of regulations in the field of physical protection was not the exhaustion of the issue addressed, but only the illustration of the evolution of the institutions in time and the identification of the sources of numerous controversies. The limited space did not allow us to discuss other related topics such as disputes concerning the authorization required for the conclusion of certain acts by the incapacitated or restricted person. Often, those interested in obtaining an authorization are caught between the misunderstandings between the guardianship authority and the courts, without being able to complete their approach.

As we have shown before, legislative hesitations have led us to a point where sometimes the courts are not guided. This is detrimental both to the individual who often does not know whom to address, as well as to justice.

We believe it would be beneficial for the attributions in the matter of the protection of the individual to be definitively brought to the competence of the guardianship authorities by giving up the role of the courts with these attributions. And from the point of view of taking a measure with speed, we believe it is desirable that the attributions in the matter of the protection of the person remain, as in the regulation of the Family Code, to the responsibility of the guardianship authorities. Courts should only be given the power to verify the legality and, possibly, the soundness of the measure taken by public authorities to ensure free access to justice. 